\title{
Wilson's disease: the $60^{\text {th }}$ anniversary of Walshe's article on treatment with penicillamine
} Doença de Wilson: $060^{\circ}$ aniversário do artigo de Walshe no tratamento com penicilamina Hélio A. G. Teive1, Egberto Reis Barbosa², Andrew J. Lees ${ }^{3}$

\begin{abstract}
This historical review describes Professor Walshe's seminal contribution to the treatment of Wilson's disease on the $60^{\text {th }}$ anniversary of his pioneering article on penicillamine, the first effective treatment for the condition.
\end{abstract}

Keywords: hepatolenticular degeneration; therapeutics; penicillamine.

\section{RESUMO}

Esta revisão histórica enfatiza a contribuição seminal do Professor Walshe no tratamento da doença de Wilson (DW), com o seu trabalho pioneiro sobre o uso de penicilamina, o primeiro tratamento efetivo do mundo, publicado 60 anos atrás.

Palavras-chave: degeneração hepatolenticular; terapêutica; penicilamina.

Wilson's disease $(\mathrm{WD})$ is a rare autosomal recessive metabolic disease resulting from mutations in the $A T P 7 B$ gene, which has been mapped to chromosome 13q14, gene encodes a copper-transporting adenosine triphosphatase (ATPase) protein, which is expressed most abundantly in the liver and is responsible for biliary copper excretion. Because of defects in this gene, copper accumulates in several organs, especially the liver, brain (basal ganglia) and corneas $^{1,2}$. Clinically, patients present with predominantly hepatic, psychiatric and neurological symptoms, particularly dystonia, tremor and parkinsonism. The Kayser-Fleischer ring is an important physical sign, and the most important laboratory tests are serum ceruloplasmin and urine copper lev$\mathrm{els}^{1,2}$. The worldwide prevalence of WD is 1:30,000 and more than 400 distinct disease-causing mutations in the $A T P 7 B$ gene associated with WD have been identified ${ }^{1,2}$. Treatment options for WD patients include copper chelating agents such as penicillamine, trientine, ammonium tetrathiomolybdate and zinc salts ${ }^{1,3}$. First used in patients with WD 60 years ago, penicillamine is considered the most effective treatment for the condition ${ }^{1.3}$. This review describes historical aspects of WD and emphasizes the important contribution made by Professor Walshe to the treatment of this disease with his pioneering use of penicillamine.

\section{WILSON'S DISEASE - HISTORICAL MILESTONES}

Samuel Alexander Kinnier Wilson (1878-1937) published his masterpiece "Progressive lenticular degeneration: a familial nervous disease associated with cirrhosis of the liver" in $1912^{1,3}$. He described twelve patients: four cases he had seen himself, two additional cases from the records of the National Hospital, Queen Square, London, UK, and six cases previously published in the literature ${ }^{1}$. From 1913 to 1952, several researchers published important contributions to the understanding of WD, including: Rumpel (described excess copper in the liver), Gerlach and Rohrscheiner (reported excess copper in corneal rings), Kayser, Fleischer (Kayser-Fleischer corneal ring), Hall (introduced the term hepatolenticular degeneration), Cumings (suggested treatment with British antilewisite), Bearn and Kunkel, and Schieberg and Gitlin (reported deficiency of ceruloplasmin in the serum) ) $^{1,3}$. Three years later, Walshe proposed the use of penicillamine for WD treatment, and his seminal paper was published in 1956 1,4,5. Five years after that, Schouwink described the use of zinc salts in the treatment of WD ${ }^{1,3}$, and in 1969 and 1984, Walshe reported the use of trientine and tetrathiomolybdate, respectively, for this condition $^{1,3}$. In 1982, Starzl et al. published the first report of liver transplantation for $\mathrm{WD}^{1.3}$, and in 1993, three different groups identified the gene responsible for WD on chromosome 13q14 $14^{1,3}$.

${ }^{1}$ Universidade Federal do Paraná, Hospital de Clínicas, Serviço de Neurologia, Unidade de Distúrbios dos Movimentos, Curitiba PR, Brasil;

${ }^{2}$ Universidade de São Paulo, Faculdade de Medicina, Hospital das Clínicas, Departamento de Neurologia, São Paulo SP, Brasil;

${ }^{3}$ UCL Institute of Neurology, Reta Lila Weston Institute for Neurological Studies, Department of Molecular Neuroscience, London, UK.

Correspondence: Hélio A. G. Teive; Rua General Carneiro, 1103/102; 80060-150 Curitiba PR, Brasil; E-mail: hagteive@mps.com.br

Conflict of interest: There is no conflict of interest to declare.

Received 15 May 2016; Received in final form 17 July 2016; Accepted 28 September 2016. 


\section{JOHN M. WALSHE AND PENICILLAMINE}

Walshe (Figure 1) worked with penicillamine (dimethylcysteine), a product of the hydrolysis of penicillin, in the early 1950s in Prof. Charles Dent's laboratory at University College Hospital, London, $\mathrm{UK}^{1,3,4}$. He subsequently moved to the liver unit in the Thorndike Memorial Laboratory at Boston City Hospital, Boston, USA, where he worked under the supervision of Prof. Charles Davidson ${ }^{1,3,4}$. In the same hospital, Prof. Denny-Brown was working on WD and treating patients with British antilewisite, a drug with important side effects ${ }^{14}$. Based on his previous studies, Walshe suggested to Prof. Davidson that penicillamine could be used as a copper-chelating drug ${ }^{4}$. Following this suggestion, penicillamine was used in one patient with WD, and an increase in his urinary copper excretion was observed. However, because of various problems, additional tests proved inconclusive $^{1,4}$. Walshe then returned to the UK and restarted his studies with penicillamine in WD patients. The first WD patient to use penicillamine regularly was Ms S.F., who started treatment in 1955, and after one year of follow-up, clinical examination showed that penicillamine had been effective ${ }^{1,4}$. In 1956, Walshe published a paper in the American Journal of Medicine under the title "Penicillamine, a new oral therapy for Wilson's dis-

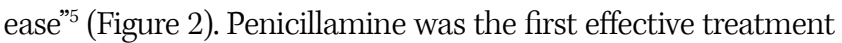
for patients with WD. However, initial reactions from other researchers studying WD were less than enthusiastic, and both Denny-Brown in the USA and Cumings in London were very critical of Walshe's discovery'. In 1960, Walshe published another paper on the treatment of WD with penicillamine in The Lancet 6 . Ten years after penicillamine was first used to treat WD, its toxicity became evident and several side effects were observed. These were related to immunologically-mediated reactions,

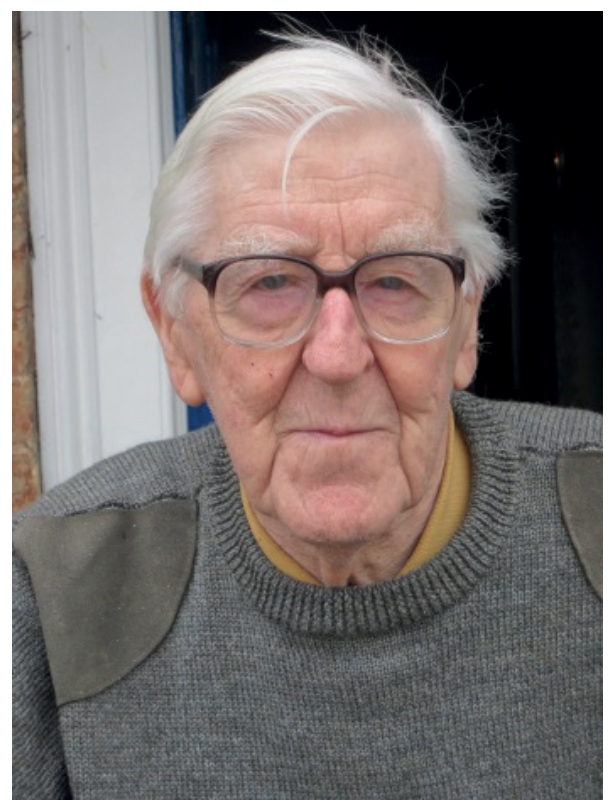

(Courtesy of Professor Walshe)

Figure 1. J. M. Walshe (1920-). including skin lesions (elastosis perforans serpiginosa, epidermolysis bullosa), systemic lupus erythematosus, nephrotic syndrome, Goodpasture syndrome, Ehlers-Danlos syndrome, myasthenia gravis, polymyositis, thrombocytopenia and agranulocytosis $\mathrm{s}^{4.7}$. In some patients using penicillamine, a worsening of the neurological clinical picture (dystonia, parkinsonism) was observed ${ }^{47}$. Walshe and Yealland found these unexplained side effects in 11 of 137 patients with predominantly neurological signs. Various hypotheses have been put forward to explain this paradoxical worsening of neurological symptoms, including a sudden release of ionic copper, the redox potential of copper, a low level of urate in the plasma following treatment with penicillamine and genetic mechanisms (unfavorable mutations in the $A T P 7 B$ gene $)^{4,7}$. The neurotoxicity and reversible side effects of penicillamine motivated various researchers, including Prof. Walshe, to look for new drugs to treat $\mathrm{WD}^{3,4}$, and their efforts led to trientine, thiomolybdate and zinc therapy being used to treat this condition ${ }^{3,4,7}$. Although penicillamine still remains the drug of choice for the treatment of WD, in recent years it has become the subject of some controversy because of its wellknown side effects, particularly worsening of the neurological symptoms ${ }^{4}$. In 1999, the journal Movement Disorders published three very interesting papers about this controversial issue by

\section{Glinical Studies}

\section{Penicillamine, a New Oral Therapy for Wilson's Disease ${ }^{*}$}

\section{J. M. WALSHE \\ London, England}

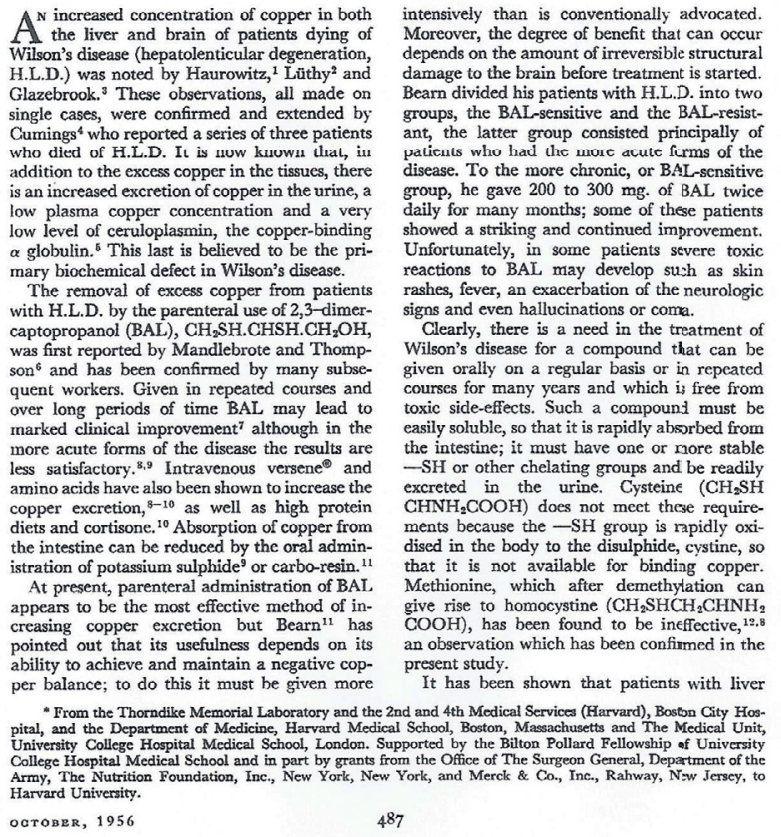

(Reproduced from reference 5)

Figure 2. Walshe's first paper about Penicillamine for treatment of Wilson's disease (1956) in the American Journal of Medicine. 
Prof. Walshe ("Penicillamine: the treatment of first choice for patients with WD"), Prof. Brewer ("Penicillamine should not be used as initial therapy in WD") and Prof. LeWitt ("Penicillamine as a controversial treatment for WD"), but no consensus about its use was reached, and penicillamine continues to be a treatment option for WD patients ${ }^{8-10}$.

\section{CONCLUSION}

Professor John Walshe pioneered the treatment of WD and discovered various drugs that can be used to treat the condition, including penicillamine, trientine and thiomolybdate. His seminal paper published 60 years ago described the first study in which penicillamine was used as oral therapy for WD. Penicillamine remains an effective drug for treating patients with WD. However, neurologists should be aware of the advantages and disadvantages associated with its use $\mathrm{e}^{3,4,7-10}$.

\section{Acknowledgment}

The authors thank Professor John Walshe, and Ms. Valerie Weather of the Wilson's disease support group UK, for their kind support.

\section{References}

1. Walshe JM. History of Wilson's disease: 1912-2000. Mov Disord. 2006;21(2):142-7. doi:10.1002/mds.20694

2. Machado A, Chien HF, Deguti MM, Cançado E, Azevedo RS, Scaff M et al. Neurological manifestations in Wilson's disease: report of 119 cases. Mov Disord. 2006;21(12):2192-6. doi:10.1002/mds. 21170

3. Walshe JM. The conquest of Wilson's disease. Brain. 2009;132(8):2289-95. doi:10.1093/brain/awp149

4. Walshe JM. The story of penicillamine: a difficult birth. Mov Disord. 2003;18(8):853-9. doi:10.1002/mds.10458

5. Walshe JM. Penicillamine, a new oral therapy for Wilson's disease. Am J Med. 1956;21(4):487-95. doi:10.1016/0002-9343(56)90066-3
6. Walshe JM. Treatment of Wilson's disease with penicillamine. Lancet. 1960;1(7117):188-92. doi:10.1016/S0140-6736(60)90109-4

7. Walshe JM. Penicillamine neurotoxicity: an hypothesis. ISRN Neurol. 2011;2011:464572. doi:10.5402/2011/464572

8. Walshe JM. Penicillamine: the treatment of first choice for patients with Wilson's disease. Mov Disord. 1999;14(4):545-50. doi:10.1002/1531-8257(199907)14:4<545::AID-MDS1001>3.0.CO;2-U

9. Brewer GJ. Penicillamine should not be used as initial therapy in Wilson's disease. Mov Disord. 1999;14(4):551-4. doi:10.1002/1531-8257(199907)14:4<551::AID-MDS1002>3.0.CO;2-S

10. LeWitt PA. Penicillamine as a controversial treatment for Wilson's disease. Mov Disord. 1999;14(4):555-6. doi:10.1002/1531-8257(199907)14:4<555::AID-MDS1003>3.0.CO;2-L 